\title{
Crop-biodiversity along altitude in Gangotri valley of Uttarkashi district of Garhwal Himalaya, India
}

\begin{abstract}
The study documents crop diversity by local inhabitants of Gangotri valley along varying altitude i.e. low $(1000-1500 \mathrm{~m})$, middle $(1500-2000 \mathrm{~m})$ and high $(2000$ $2500 \mathrm{~m}$ ) altitude. A total of 55 crop species were recorded of which 41 species were di-cotyledons and 14 species were monocotyledons. Food grains comprised of 11 species, of which eight were monocotyledons and three were di-cotyledons. Pulses comprised 11 species. Vegetable crops consisted of 32 species (10 families). Spices crops constituted five species, oil-seed three species, and two species were placed in other category. From all the families, fabaceae was the largest with 15 species. Low altitude displayed the largest number of species (54) followed by middle (49) and high (16) altitudes. Six species were restricted to low altitude only. Some species occupied two or more altitudes. It was found that altitude exerted a significant effect on climate of the area due to which some species are adapted to particular environmental conditions under agroforestry systems.
\end{abstract}

Keywords: agroforestry, indigenous crops, cash crops, hybrids
Volume 2 Issue 4 - 2018

\section{Arvind Bijalwan, Akshay Mamgain, Satendra Kumar Rathaude}

Area of Technical Forestry, Indian Institute of Forest

Management, India

Correspondence: Arvind Bijalwan, Area of Technical Forestry, Indian Institute of Forest Management, Bhopal- 462003, Madhya Pradesh, India, Email arvindbijalwan276@gmail.com

Received: June 30,2018 | Published: August 13,2018

\section{Introduction}

Agriculture is as old as the human civilizations originated and flourished. Without agriculture human being cannot sustain themselves. Crop-farming and livestock are the two main components of agriculture. In the Himalayan region, agriculture is mostly done on the sustainable basis because the main hurdles are uneven topography and fluctuating climatic conditions. The global world population has risen by $37 \%$ and food consumption by $40 \%$ since year $1990 .{ }^{1}$ In order to suffice the needs of the growing population an effort has to be made to increase the crop biodiversity and agriculture production.

There are less studies documenting in the plant diversity in Uttarkashi, agriculture status, ${ }^{2,3}$ vegetation diversity ${ }^{4}$ and tree distribution and regeneration, ${ }^{5}$ however, the research listing the major cultivated crop plant species in Uttarkashi district is missing. Hence the main aim of this study was to list the different crop plant species growing along varying altitude.

\section{Materials and methods}

The study was conducted on agricultural farms having trees on bunds in the Gangotri valley of Uttarkashi district of Uttarakhand, India along varying altitude (low $=1000-1500 \mathrm{~m}$, middle $=1500-2000 \mathrm{~m}$ and high $=2000-2500 \mathrm{~m})$ in six villages namely, Siror $(1394 \mathrm{~m})$ and Netala (1459m) falls in the low altitude, Silla (1765m) and Malla $(1837 \mathrm{~m})$ in middle and Jhala $(2213 \mathrm{~m})$ and Sukki $(2500 \mathrm{~m})$ in high altitude. Random quadrats were laid according to the species area curve method and crop-biodiversity of the area was analyzed. Crop species were identified by using published book of flora, ${ }^{6}$ taking help from agriculture science centre ('Krishi Vigyan Kendra', KVK) and consulting villagers. Informal inspection was also conducted among the villagers to evaluate the agriculture situation of the area.

\section{Results and discussion}

In this study, a total of 55 crop plant species were recorded of which 41 species $(75 \%)$ were of di-cotyledons and monocotyledons constituted 14 species (25\%) (Figure 1). Low altitude displayed largest crop diversity with all species found growing in this zone, closely followed by middle (49 species) and then high (16) altitudes (Figure 2). Six species were restricted to low altitude only, namely, Arachis hypogaea, Cajanus cajan, Cicer arietinum, Pennisetum glaucum, Saccharum officinarum and Sorghum bicolor. 33 species were found growing in both low and middle altitude and 15 species was found growing in all the three altitudes (Table 1).

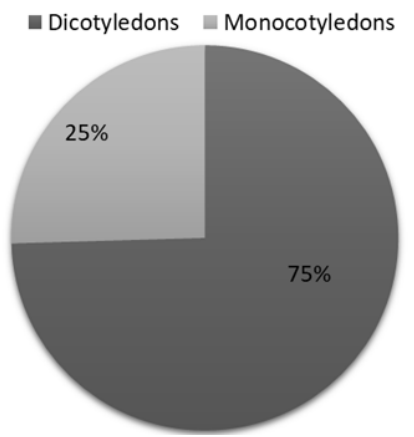

Figure I Crop plant species among di-cotyledons and monocotyledons (\%).

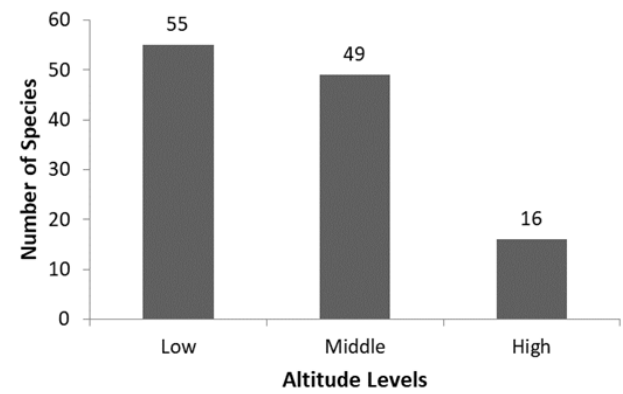

Figure 2 Distribution of crop plant species along altitude. 
From all the 55 species the largest family was found to be fabaceae with 15 species followed by poaceae (nine species), cucurbitaceae (eight), brassicaceae (five), amaranthaceae, solanaceae each having four species, amaryllidaceae, apiaceae, zingiberaceae each with two species and remaining families each containing one species.

In the economically useful category of species, 11 species were of food grains of which three are pseudo-cereal (Amaranthus caudatus, A. cruentus and A. hypochondriacus), four are millets (Echinochloa frumentacea, Eleusine coracana, Pennisetum glaucum and Sorghum bicolor) and rest are cereal crops. Among the food grains, poaceae was the largest family with eight species. Pulses (fabaceae) constituted 11 species, of which only two species were indigenous (Macrotyloma uniflorum and Vigna umbellata). Between vegetable species, there were 32 species distributed across 10 families of which cucurbitaceae was found to be largest having eight species, followed by fabaceae (seven sp.), brassicaceae (five), amaranthaceae and solanaceae (four species each), apiaceae (two) and rest of the family each having one species. Spices comprised five species (Capsicum annuиm,

Table I Crop-biodiversity along elevation in agroforestry systems on farm land

Family

Food Grains

Amaranthaceae

Poaceae
(Gramineae)
Species

Vernacular name

Chawlai,

Ramdana

Amaranthus caudatus L.

Chawlai,

A. cruentus L.

A. hypochondriacus $\mathrm{L}$.

Echinochloa

frumentacea Link

Eleusine coracana

Gaertn.

Hordeum vulgare L.

Oryza sativa L.

Pennisetum glaucum

(L.) R. Br.

Sorghum bicolor (L.)

Moench

Triticum aestivum L.

Gehun

Makka, Makki
Coriandrum sativum, Curcuma longa, Trigonella foenum-graecum and Zingiber officinale). Oil seed crops have only three species: Arachis hypogaea, Brassica juncea and Glycinemax and other crops contained two species (Table 1) (Figure 3).

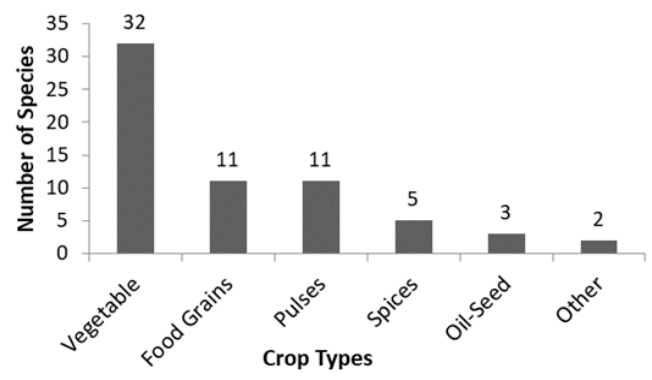

Figure 3 Distribution of agricultural crops in different category of crops.
Other use

name

Grain

amaranth preparations)

Grain Seeds are used in halva and

Amaranth, 'laddoos' (Indian sweet

Red amaranth preparations)

Seeds are used in halva and

'laddoos' (Indian sweet

preparations)

Seeds used in 'kheer' (pudding/ porridge)

Flour used in halva (Indian sweet preparation)

Used as fodder and in religious rituals

Seeds used in 'kheer' (pudding/ porridge), crop residue used as fodder

$L, M, H$

$L, M, H$

$L, M$

, M

Used as animal fodder

L

$\mathrm{L}$

Flour used in halva (Indian sweet preparation)

L, M

Chappatis, crop residue used as fodder 
Table Continued

\begin{tabular}{|c|c|c|c|c|c|}
\hline Family & Species & $\begin{array}{l}\text { Vernacular } \\
\text { name }\end{array}$ & $\begin{array}{l}\text { English } \\
\text { name }\end{array}$ & Other uses & Elevation \\
\hline \multicolumn{6}{|l|}{ Pulses } \\
\hline \multirow[t]{10}{*}{$\begin{array}{l}\text { Fabaceae } \\
\text { (Leguminosae) }\end{array}$} & $\begin{array}{l}\text { Cajanus cajan (L.) } \\
\text { Millsp. }\end{array}$ & Arhar,Tor & Pigeon pea & Leaves used as fodder & L, M \\
\hline & Cicer arietinum L. & Chana & Chickpea & Leaves used as fodder & L \\
\hline & Glycine max (L.) Merr. & Bhat & Soybean & $\begin{array}{l}\text { Seeds roasted then eaten, crop } \\
\text { residue used as fodder }\end{array}$ & L, M \\
\hline & $\begin{array}{l}\text { Lablab purpureus (L.) } \\
\text { Sweet }\end{array}$ & Seimi & Bean & & L, M \\
\hline & Lens culinaris Medikus & Masoor & Lentil & & L, M \\
\hline & $\begin{array}{l}\text { Macrotyloma uniflorum } \\
\text { (Lam.) Verdc. }\end{array}$ & Gahat & Horse Gram & $\begin{array}{l}\text { Seeds used as stuffing for } \\
\text { 'pranthas' (unleavened bread); } \\
\text { boiled seeds given to remove } \\
\text { kidney and urinary stones }\end{array}$ & L, M \\
\hline & Phaseolus vulgaris L. & Rajma & Kidney Bean & & L, M, H \\
\hline & $\begin{array}{l}\text { Pisum sativum L. [Pisum } \\
\text { sativum subsp. arvense } \\
\text { (L.) Asch. \& Graebn] }\end{array}$ & Matar & Pea & & L, M, H \\
\hline & $\begin{array}{l}\text { Vigna mungo (L.) } \\
\text { Hepper }\end{array}$ & Urad & Black Gram & & L, M \\
\hline & $\begin{array}{l}\text { V. umbellata (Thunb.) } \\
\text { Ohwi \& H. Ohashi }\end{array}$ & Naurangi & Rice Bean & & L, M \\
\hline & V. unguiculata (L.) Walp. & Lobia & Cowpea & & L, M \\
\hline
\end{tabular}

Vegetables

\begin{tabular}{|c|c|c|c|c|c|}
\hline \multirow[t]{2}{*}{ Amaranthaceae } & Amaranthus species & Chaulai & Amaranth & $\begin{array}{l}\text { Leaves used as stuffing for } \\
\text { 'pranthas' (unleavened bread) } \\
\text { and in 'pakoras' }\end{array}$ & $\mathrm{L}, \mathrm{M}, \mathrm{H}$ \\
\hline & Spinacia oleracea L. & Palak & Spinach & $\begin{array}{l}\text { Leaves used as stuffing for } \\
\text { 'pranthas' (unleavened bread) } \\
\text { and in 'pakoras' }\end{array}$ & $L, M$ \\
\hline $\begin{array}{l}\text { Amaryllidaceae (earlier } \\
\text { placed in Alliaceae) }\end{array}$ & Allium cepa L. & Pyaz & Onion & Used as condiment and salad & L, M \\
\hline \multirow[t]{2}{*}{ Apiaceae (Umbelliferae) } & $\begin{array}{l}\text { Coriandrum sativum } \\
\text { L. }\end{array}$ & Dhania & Coriander & $\begin{array}{l}\text { Leaves used as condiment and } \\
\text { fruits used as spice }\end{array}$ & L, M \\
\hline & Daucus carota L. & Gaajar & Carrot & Used as salad & L, M \\
\hline Araceae & $\begin{array}{l}\text { Colocasia esculenta } \\
\text { (L.) Schott }\end{array}$ & Arbi, Paapad & Taro & $\begin{array}{l}\text { Leaves used as 'pakoras' (fried } \\
\text { snack) and 'patrodu' (a pancake } \\
\text { type) }\end{array}$ & $L, M$ \\
\hline
\end{tabular}


Table Continued

\begin{tabular}{|c|c|c|c|c|c|}
\hline Family & Species & $\begin{array}{l}\text { Vernacular } \\
\text { name }\end{array}$ & $\begin{array}{l}\text { English } \\
\text { name }\end{array}$ & Other uses & Elevation \\
\hline \multirow[t]{5}{*}{$\begin{array}{l}\text { Brassicaceae } \\
\text { (Cruciferae) }\end{array}$} & Brassica juncea & Rai & $\begin{array}{l}\text { Brown } \\
\text { Mustard }\end{array}$ & & L, M, H \\
\hline & $\begin{array}{l}\text { B. oleracea L. var. } \\
\text { botrytis L. }\end{array}$ & Phulgobhi & Cauliflower & Used to make 'pakoras' & L, M, H \\
\hline & $\begin{array}{l}\text { B. oleracea L. var. } \\
\text { capitata L. }\end{array}$ & $\begin{array}{l}\text { Bandhgobi, } \\
\text { PattaGobhi }\end{array}$ & Cabbage & Used as salad & L, M, H \\
\hline & B. rapavar. rapa & Shalgam & Turnip & Used as salad & L, M, H \\
\hline & $\begin{array}{l}\text { Raphanus sativus } \\
\text { L. var. (cultivar) } \\
\text { 'Longipinnatus' L.H. } \\
\text { Bailey }\end{array}$ & Mooli & Radish, Daikon & Used as salad & $L, M, H$ \\
\hline Chenopodiaceae & Beta vulgaris $\mathrm{L}$. & Chookandar & Beetroot & Used as salad & L, M \\
\hline \multirow[t]{8}{*}{ Cucurbitaceae } & $\begin{array}{l}\text { Benincasa } \\
\text { hispida(Thunb.) } \\
\text { Cogn. }\end{array}$ & Tarbooz, Petha & $\begin{array}{l}\text { White Gourd, } \\
\text { Ash Gourd }\end{array}$ & & L, M \\
\hline & Cucumis sativus $\mathrm{L}$. & Kheera & Cucumber & Used as salad & L, M \\
\hline & $\begin{array}{l}\text { Cucurbita } \\
\text { argyrosperma K. } \\
\text { Koch }\end{array}$ & Kaddu, Sitaphal & $\begin{array}{l}\text { Japanese pie } \\
\text { pumpkin }\end{array}$ & $\begin{array}{l}\text { Flowers are used to make } \\
\text { 'pakoras' }\end{array}$ & L, M, H \\
\hline & $\begin{array}{l}\text { C. maxima } \\
\text { Duchesne }\end{array}$ & Kaddu, Sitaphal & $\begin{array}{l}\text { Cultivated } \\
\text { Squash }\end{array}$ & $\begin{array}{l}\text { Flowers are used to make } \\
\text { 'pakoras' }\end{array}$ & L, M, H \\
\hline & $\begin{array}{l}\text { C. moschata } \\
\text { Duchesne ex Poir. }\end{array}$ & Kaddu, Sitaphal & Pumpkin & $\begin{array}{l}\text { Flowers are used to make } \\
\text { 'pakoras' }\end{array}$ & L, M, H \\
\hline & $\begin{array}{l}\text { C. pepo L.var. pepo } \\
\text { L. Bailey }\end{array}$ & Kaddu, Sitaphal & Field Pumpkin & $\begin{array}{l}\text { Flowers are used to make } \\
\text { 'pakoras' }\end{array}$ & L, M, H \\
\hline & $\begin{array}{l}\text { Lagenaria siceraria } \\
\text { (Molina) Standl. }\end{array}$ & Launki & $\begin{array}{l}\text { Bottle gourd, } \\
\text { Calabash }\end{array}$ & & L, M \\
\hline & $\begin{array}{l}\text { Luffa cylindrical M. } \\
\text { Roem. }\end{array}$ & Tori & Sponge gourd & & L, M \\
\hline \multirow[t]{7}{*}{$\begin{array}{l}\text { Fabaceae } \\
\text { (Leguminosae) }\end{array}$} & $\begin{array}{l}\text { Cyamopsis } \\
\text { tetragonoloba (L.) } \\
\text { Taub. }\end{array}$ & Gawar phalli & $\begin{array}{l}\text { Guar, Cluster } \\
\text { Bean }\end{array}$ & & L, M \\
\hline & $\begin{array}{l}\text { Lablab purpureus (L.) } \\
\text { Sweet }\end{array}$ & Seimi & $\begin{array}{l}\text { Hyacinth bean, } \\
\text { Indian Bean }\end{array}$ & & L, M \\
\hline & Phaseolus vulgaris $\mathrm{L}$. & Pharas Bean & $\begin{array}{l}\text { Common } \\
\text { Bean, Green } \\
\text { Bean, French } \\
\text { Bean }\end{array}$ & $\begin{array}{l}\text { Seed flour used to make } \\
\text { 'pakoras' }\end{array}$ & L, M, H \\
\hline & $\begin{array}{l}\text { Pisum sativum L. } \\
\text { [Pisum sativum } \\
\text { subsp. arvense (L.) } \\
\text { Asch. \& Graebn] }\end{array}$ & Matar & Pea & & $\mathrm{L}, \mathrm{M}, \mathrm{H}$ \\
\hline & $\begin{array}{l}\text { Trigonella foenum- } \\
\text { graecum L. }\end{array}$ & Methi & Fenugreek & $\begin{array}{l}\text { Seeds used as spice and } \\
\text { condiment }\end{array}$ & L, M \\
\hline & Vicia faba L. & Semi & $\begin{array}{l}\text { Broad Bean, } \\
\text { Fava Bean }\end{array}$ & & L, M \\
\hline & $\begin{array}{l}\text { Vigna unguiculata } \\
\text { (L.) Walp. }\end{array}$ & Lobia & Cowpea & & L, M \\
\hline
\end{tabular}


Table Continued

\begin{tabular}{|c|c|c|c|c|c|}
\hline Family & Species & $\begin{array}{l}\text { Vernacular } \\
\text { name }\end{array}$ & $\begin{array}{l}\text { English } \\
\text { name }\end{array}$ & Other uses & Elevation \\
\hline Malvaceae & $\begin{array}{l}\text { Abelmoschus } \\
\text { esculentus (L.) } \\
\text { Moench }\end{array}$ & Bhindi & $\begin{array}{l}\text { Lady Finger, } \\
\text { Okra }\end{array}$ & & L, M \\
\hline \multirow[t]{4}{*}{ Solanaceae } & Capsicum annuum L. & Shimla Mirch & Bell Pepper & & $L, M$ \\
\hline & $\begin{array}{l}\text { Solanum } \\
\text { lycopersicum L. } \\
\text { [Syn. Lycopersicon } \\
\text { esculentum Mill.] }\end{array}$ & Tamaatar & Tomato & Used to make 'chutney' (Sauce) & L, M, H \\
\hline & S. melongena $\mathrm{L}$. & Baigan & $\begin{array}{l}\text { Brinjal, } \\
\text { Eggplant, } \\
\text { Aubergine }\end{array}$ & Used to make 'pakoras' & L, M \\
\hline & S. tuberosum L. & Aaloo & Potato & Used to make 'pakoras' & $L, M, H$ \\
\hline
\end{tabular}

Oil-seed

\begin{tabular}{|c|c|c|c|c|c|}
\hline $\begin{array}{l}\text { Brassicaceae } \\
\text { (Cruciferae) }\end{array}$ & $\begin{array}{l}\text { Brassica juncea (L.) } \\
\text { Czern. }\end{array}$ & Rai & $\begin{array}{l}\text { Brown } \\
\text { Mustard }\end{array}$ & & $L, M, H$ \\
\hline \multirow[t]{2}{*}{$\begin{array}{l}\text { Fabaceae } \\
\text { (Leguminosae) }\end{array}$} & Arachis hypogaea $\mathrm{L}$. & Moong phalli & Groundnut & Seeds roasted then eaten & $\mathrm{L}$ \\
\hline & Glycine $\max ($ L.) Merr. & Bhat & Soybean & & L, M \\
\hline Pedaliaceae & Sesamum indicum L. & Til & Sesame & $\begin{array}{l}\text { Seeds eaten raw and used to } \\
\text { make 'laddoos' (Indian sweet } \\
\text { preparations) }\end{array}$ & $\mathrm{L}$ \\
\hline \multicolumn{6}{|l|}{ Spices } \\
\hline Solanaceae & Capsicum annuum L. & Mirch & Chili Pepper & Used to make pickle & L, M \\
\hline \multirow[t]{2}{*}{ Zingiberaceae } & Curcuma longa $\mathrm{L}$. & Haldi & Turmeric & $\begin{array}{l}\text { Used for medicinal and religious } \\
\text { purpose }\end{array}$ & L, M \\
\hline & $\begin{array}{l}\text { Zingiber officinale } \\
\text { Roscoe }\end{array}$ & Adrak & Ginger & Used for medicinal purpose & $L, M$ \\
\hline \multicolumn{6}{|l|}{ Other } \\
\hline $\begin{array}{l}\text { Amaryllidaceae } \\
\text { (earlier placed in } \\
\text { Alliaceae) }\end{array}$ & Allium sativum $\mathrm{L}$. & Lahsun, Lassun & Garlic & $\begin{array}{l}\text { Used as condiment and } \\
\text { medicine }\end{array}$ & $L, M$ \\
\hline Poaceae & $\begin{array}{l}\text { Saccharum officinarum } \\
\text { L. }\end{array}$ & Ganna & Sugarcane & Used for juice & $\mathrm{L}$ \\
\hline
\end{tabular}

L, low altitude (I000-I500m); M, middle altitude (I500-2000m); H, high altitude $(2000-2500 \mathrm{~m})$

Some species have one major purpose e.g. spice (Capsicum annum, chili; Curucuma longa and Zingiber officinale) and minor usage is in pickles and in medicine. Further, some crop plants have two major uses e.g. leaves of all the pseudo-cereals are also used as vegetable, unripe fruit of some pulses are used as vegetable (Lablab purpureus, Phaseolus vulgaris and Pisum sativum) and ripe fruit as oil-seed crop (Glycine max), fruits and seeds of some vegetables are used as spice (Coriandrum sativum and Trigonella foenum-graecum), vegetables as salad [Beta vulgaris, Brassica oleracea var. capitata, Daucus carota, Raphanus sativus L. var. (cultivar) 'Longipinnatus',

Solanum lycopersicum], seeds of vegetable as oil-seed crop (Brassica juncea). Further, some crop plants have miscellaneous uses also such as fodder, medicine, religious rituals and in preparation of traditional recipes (Table 1 ).

Most of the crops were found growing in low and middle altitude because people have domesticated these crops over many years and thus, they have developed their own varieties of different crop plants which have adapted to existing climatic conditions of the area. In the high altitude very less crops were observed and the reason could be 
the harsh climatic conditions offered by the high altitude.

Generally, the agriculture in the Gangotri valley is practiced by people such as: less educated who cannot do other jobs, women whose spouse are employed in city/town and those who have a large amount of ancestral land. It has been found that very few farmers plant indigenous crops (e.g. millets and pseudo-cereal) or even if it is planted the land acreage under cultivation is reduced because in the recent period people's acceptability towards indigenous crops has declined and therefore, these crops do not offer good return to farmer. These indigenous crops are grown from an ancient time and their land races have been selected and domesticated carefully by the farmers in relation to environmental conditions prevalent in the mountain ecosystem and thus, are better adapted to these conditions. Among the pulses, the indigenous crops grown are: horse gram and rice bean. Further, some indigenous crops were found to be completely neglected or grown by very few farmers such as, Fagopyrum esculentum (common buckwheat, 'Oggal'/'Ougal'), F. tataricum (tartary buckwheat, 'Phaphar'), Panicum miliaceum (proso millet, 'Cheena') and Setaria italica (foxtail millet, 'Kauni'). These indigenous crops if planted along with cash crops will provide additional benefit to farmers because they are more nutritious than other food grains, climate adaptable, require less maintenance and soil nutrients and also their genetic heritage will be preserved. It has been found that farmers themselves are buying these crops from the market at excessive price for self-consumption purpose and city people are also developing a taste for these crops due to their beneficial effects in some disorders such as diabetes, obesity, arthritis etc.

Most of the farmers have switched to cultivating cash crops (e.g. cabbage, capsicum, cauliflower, potato, pea, soybean and tomato) because these crops have good demand in market and thus, make the farmer financially more secure after crop harvest. Further, the crop loan and insurance for these crops are easily available as compared to indigenous crops. However, these cash crops have some drawbacks also, such as farmers use hybrid seeds, which are costly and during each sowing the seeds have to be bought again and again by the farmer. Further, these cash crops require more fertilizers and are labour intensive. Increase in usage of chemical fertilizer will acidify the crop fields and consequently, after some years of good yield the productivity will decline. It was reported by high altitude village farmers (Sukki and Jhala) that their main income source are cash crops (apple, potato, kidney bean and amaranth) and if they stop cultivating these crops then their financial system will crash.

The agriculture done by the people in the valley is generally traditional (i.e. not utilizing much scientific methodology) and mostly done for sustenance purpose. Presently, the agriculture crops are grown as monoculture on agriculture field in the Gangotri valley and thus, there is increase in incidence of disease attack on crop plants, decline in crop specific nutrients of soil, decrease in bio-diversity and heavy use of fertilizers and crop protection chemicals thus, causing environmental deterioration. One solution could be to employ the method of inter-cropping (mixed/multiple cropping), wherein two or more than two crops are grown simultaneously on the same piece of land.

If these indigenous crops are grown in a mix with other crops using appropriate technical guidance, then crop yield will improve and also there will be less attack of insect/pathogen. Further, cash crops cannot be ignored completely and therefore, these crops should be grown in combination with indigenous crops, which are nutritious and cheap and thus, are in reach of monetary poor people. To improve the agriculture condition, some agroforestry tree species should also be promoted among the farmers so as to reduce the burden of farmers for relying solely on the agriculture crops for their daily domestic needs.

\section{Conclusion}

The study concludes that with increase in altitude there is decrease in crop-biodiversity. The study finds that there is decrease in cultivated area of indigenous crops and also farmers are abandoning agriculture due to financial uncertainty in agriculture and preferring jobs, which offer a secure capital. Thus, in order to uplift the status of farmer modern agriculture techniques with traditional knowledge should be combined in order to create a more feasible, and financially secure agro-ecosystem.

\section{Acknowledgements}

The authors are thankful to Director, Indian Institute of Forest Management, Bhopal for necessary support provided to conduct this study. The authors are also thankful to International Papers (IP), Hyderabad for providing financial assistant and implementation through IP-IIFM Paul Brown Centre of Excellence to conduct the study "Community Livelihood promotion through assessment of Biodiversity and Carbon Sequestration potential in Agroforestry systems along altitude and aspects of Western Himalaya (Project No. IIFM/AB/Ext./Res/Proj./2016/03). The authors extend thanks to local community of the study area for providing necessary support and information during field work.

\section{Conflict of interest}

Author declares there is no conflict of interest in publishing the article.

\section{References}

1. FAO. State of the World's Forests 2016. Forests and agriculture: land-use challenges and opportunities. Food and Agriculture Organization of the United Nations, Rome; 2016. 107. p.

2. Rawat VS. Land utilization farming with reference to Uttarkashi, the hilly district of Uttarakhand. Researcher. 2009;1(6):41-47.

3. Bisht $\mathrm{C}$, Badoni A. Distribution and indigenous uses of some medicinal plants in district Uttarkashi, Uttarakhand, India. Researcher. 2009;1(6):38-40.

4. Bijalwan A, Singh S. Vegetational diversity along altitudinal gradients in the upper Yamuna forest division of Uttarakhand, India. Asian Journal of Science and Technology. 2013;4(3):28-32.

5. Bijalwan A, Dobriyal MJR. Geometry, distribution and regeneration pattern of trees in agroforestry systems along altitude and aspects in the upper Yamuna region of Uttarakhand Himalaya, India. Applied Ecology and Environmental Sciences. 2016;4(1):15-25.

6. Gaur RD. Flora of the District Garhwal: North West Himalaya (with ethnobotanical Notes). Transmedia, Srinagar, Garhwal; 1999. 